\title{
Pensar juntos: intelectuales, perspectivas y prospectivas de la crisis del 2020
}

Thinking Together: Intellectuals, Perspectives

and Prospects in 2020 crisis

https://doi.org/10.48102/if.2021.v1.n2.169

\author{
Anna María Fernández Poncela* \\ fpam1721@correo.xoc.uam.mx \\ ORCID: https://orcid.org/0000-0003-3080-212X \\ Doctora en Antropología \\ Universidad Autónoma Metropolitana \\ México
}

\section{Resumen}

En todas las sociedades, los intelectuales -y la gente en general- tienen ideas sobre el pasado, el presente y el futuro, desde memorias, historias, cosmovisiones e ideologías hasta utopías o distopías; narrativas e interpretaciones fruto del pensamiento humano que, en ciertas circunstancias y coyunturas importantes, resurgen para analizar y caracterizar procesos, proponiendo o esbozando posibilidades sobre el porvenir. En este artículo, se realiza una revisión provisional de los análisis y proyecciones sociológicas situadas y posicionadas, mediante escritos y declaraciones de pensadores contemporáneos considerados referentes en el marco de las ciencias sociales, con relación a la pandemia del año 2020. Se trata de presentar sus perspectivas y prospectivas de la dimensión social de la crisis según

\footnotetext{
* Doctora en Antropología por la Universidad de Barcelona; profesora de la Universidad Autónoma Metropolitana Unidad Xochimilco; miembro de la Academia Mexicana de Ciencias y del Sistema Nacional de Investigadores. Sus líneas de investigación son la participación y cultura política, y la cultura popular.
} 
dos tendencias semánticas: las oportunidades y miradas esperanzadoras, y los riesgos y voces pesimistas; ello mediante un análisis documental de sus exposiciones y la clasificación de enfoques. Como resultado, cabe adelantar que la visión optimista es mayoritaria, aunque matizada, y que hay especial énfasis en la revisión de la vida social y su reordenamiento para un mundo mejor.

\section{Palabras clave}

Intelectuales, reflexión, crisis pandémica, miradas, narrativas.

\section{Abstract}

In all societies, intellectuals-and people in general-have ideas about the past, present and future, from memories, histories, worldviews and ideologies to utopias or dystopias; narratives and interpretations resulting from human thought that, in certain circumstances and important situations, resurface to analyze and depict processes, proposing or outlining possibilities for the future. In this article, there is a provisory review of the analyses and sociological projections situated and set-through writings and statements of contemporary thinkers considered referents in of social sciences-in respect to the pandemic of the year 2020. The aim is to present their perspectives and prospects of the social dimension of the crisis according to a couple of semantic trends: opportunities and enthusiastic visions, and risks and pessimistic voices; this by means of a documentary analysis of their expositions and the classification of approaches. As a result, it can be said that the optimistic vision is predominant-although with some nuances-and that there is special emphasis on the revision of social life and its reordering for a better world.

\section{Keywords}

Intellectuals, reflection, pandemic crisis, looks, narratives.

\section{Introducción}

Lo que atormenta a los hombres no es la realidad sino la idea que se hacen de ella.

Epicteto 


\section{Sus miradas y narrativas}

Sobre los textos revisados, lo primero que salta a la vista es la rapidez con la que los intelectuales opinan: a veces, motu proprio; otras, instigados por los medios de comunicación masiva en la búsqueda de la noticia. De ahí que haya que contextualizar algunas ideas en la urgencia y la ocurrencia.

Lo segundo es la diversidad de opiniones; no sólo en el sentido de interpretar la realidad de hoy y de proponer posibles escenarios futuros, sino también de presentar miradas totalmente opuestas y enfrentadas, incluso autocontradictorias o ambiguas. No extrañará esta gama de predicciones - quizá se debería decir diagnósticos o pronósticos- a quienes recuerden las visiones de los intelectuales sobre el futuro del mundo tras la caída del muro de Berlín en 1989 o la disolución de la URSS en 1991. Tampoco debería sorprendernos el enfrentamiento de perspectivas disímiles, incluso polarizadas, en un mundo dinámico y dicotómico; no obstante, quizá llegó el momento de entablar diálogos y encuentros, pues estamos en el mismo barco: el planeta Tierra. Esto, sobre todo, en un momento en el que la derecha y la izquierda se han desdibujado y diversas posiciones políticas parecen reconfigurarse desde la biología y la ideología, desde la tecnología y la humanidad.

En tercer lugar, el contenido de estos textos se trata a veces de simples opiniones; otros son borradores de proyectos sociales. Ambas expresiones analizan el pasado-presente desde su visión (perspectiva) y muestran -principalmente- lo que nos interesa en estas páginas: cómo imaginan y esbozan el futuro (prospectiva). Todo ello según sus propios enfoques, análisis e interpretaciones vertidos en discursos y narraciones sobre el diseño de la sociedad, la economía, la política, la ecología y, en algunos casos, la tecnología y la comunicación, además de la cultura.

Por supuesto, estos discursos se construyen según sus creencias e ideologías, sus perspectivas teóricas y visiones políticas, sus formas de mirar, explicar, comprender y comunicar el mundo y la vida. Esto contribuye en la tarea de profundizar y expandir, en parte, las múltiples causas de la coyuntura mundial que vivimos y que varios señalan; sobre todo, en cuanto a los posibles desarrollos y consecuencias, nuevas y diversas configuraciones sociales hacia las cuales nos dirigimos -o a las cuales parecemos regresar-, sin descartar el ilusionismo, producto de tendencias ideológicas, inclinaciones o deseos personales y resultado de la precipitación misma. Todo esto como pensamiento disruptivo y emergente, en un primer momento, 
que permite ampliar y ahondar en la información para crear y recrear conocimiento con la finalidad de llegar a la reflexión serena y sabia que se precisa en nuestros días. Una suerte de compartir reflexiones y pensar juntos.

\section{Nuestras intenciones}

En cuanto a lo que se pretende, lo primero es plantear una o varias preguntas centrales, relacionadas con el objetivo de estas páginas: ¿cuáles son las miradas de los intelectuales sobre la crisis actual y las prospectivas sociales?, ¿qué ha aportado el contexto de la pandemia a la concepción de los riesgos, las oportunidades y el pensamiento de la sociedad presente y, sobre todo, futura desde la perspectiva de las ciencias sociales?

Lo segundo es que esto se hace a través de una lectura y revisión pormenorizada de los textos y entrevistas, con algunas técnicas de análisis de contenido y de discurso, aplicadas de un modo flexible, pues lo que más nos interesa es ver qué expresiones se vierten y qué sociedad dibujan: sus características y tendencias, utopías y distopías; también nos interesa todo lo referente al panorama reflexivo de la sociedad, con objeto de invitar a la reflexión en general.

Lo tercero es remarcar que nos centramos en la dimensión social; no se aborda la situación sanitaria, si bien los autores revisados externan algunas opiniones acordes, en general, a la información oficial, por lo que no hay mucho que decir al respecto. Lo importante es revisar el discurso y los mensajes de intelectuales "de renombre", "reconocidos", "expertos", "referentes" de la sociedad contemporánea, que externaron públicamente su parecer sobre el tema aquí abordado -ya sea en conferencias reseñadas por la prensa, entrevistas en los medios, libros, capítulos de libros o artículos de revistas- desde las primeras semanas tras la proclamación oficial de la pandemia por parte de la Organización Mundial de la Salud (OMS) en febrero del 2020 hasta finales de ese año. ${ }^{1}$

El cuarto punto, para ir cerrando esta breve presentación del tema, es señalar que, de acuerdo con un trabajo sobre las metáforas empleadas por dos periódicos en México para dar información sobre el virus A (H1N1)

1 Cabe aclarar que la selección de los discursos se basó, en primer lugar, en su carácter público; en segundo, en su procedencia de diferentes disciplinas sociales y enfoques ideológicos, con objeto de tener diversidad; en tercero, que los pensamientos y obras de sus autores tuvieran cierta vigencia en la historia reciente y en la academia en la actualidad.

Fernández, A. M. (2021). Pensar juntos: intelectuales, perspectivas y prospectivas de la crisis del 2020. Iberoforum. Revista de Ciencias Sociales, Nueva Epoca, 1(2), 1-36, Artículos, e000169. https://doi.org/10.48102/if.2021.v1.n2.169 Licencia Pública Internacional - CC BY-NC-ND 4.0 
-que provocó la pandemia de influenza en 2009-, el virus fue caracterizado así: en el plano de lo social, es un maestro, costoso socialmente y agente estigmatizador; en lo económico, es un negocio, agente paralizador, costoso económicamente y complica la pobreza; en lo político, es un arma y agente develador; en cuanto a creencias, es entidad maligna, un castigo y apocalíptico (González et al., 2011). Resulta curiosa la similitud de algunas de estas descripciones con las que se pueden leer en la prensa en 2020 sobre el SARS-CoV-2 que provoca la COVID-19.

Finalmente, es necesario subrayar que, entre los autores de los relatos surgidos en la coyuntura de la emergencia sanitaria, hay algunos que, en obras previas, han imaginado o proyectado futuros como parte de los cambios en las sociedades modernas, ruptura de seguridades tradicionales, aparición de riesgos y cómo el conocimiento y la ciencia no sólo no lleva a la certeza sino, a veces, a la incertidumbre (Douglas y Wildavsky, 1983; Giddens, 1994; Beck et al., 1997; Beck, 2002; Castel, 2004; Bauman, 2007; Lipovetsky y Charles, 2008). También hay autores que han definido futuros según sus ideas e investigaciones de cómo se desenvolverá la humanidad (Augé, 2012; Attali, 2007; Harari, 2015; Bauman, 2017). Sin embargo, en este artículo, nos enfocamos en recuperar las perspectivas a raíz de la contingencia del 2020.

\section{Algo sobre la metodología}

A modo de nota metodológica, aclaramos que lo que aquí se va a exponer es una investigación de corte cualitativo de revisión de miradas y discursos sobre la dimensión y prospectiva social de la pandemia, según los intelectuales considerados "destacados" en nuestro tiempo que escribieron u opinaron al respecto. La temporalidad va de marzo a diciembre del 2020.

Para la revisión, se tomaron en cuenta propuestas de análisis del contenido y de análisis del discurso (Fairclough, 1994; Rodríguez et al., 1996; Andréu, 2002). Se leyeron los textos y entrevistas sobre el tema, se identificaron inductivamente fragmentos, se reconstruyeron por temas y por tendencias semánticas según las partes de enunciado más representativas y, finalmente, tras una última relectura de los textos, se estableció la red semántica final, clasificada en dos tendencias básicas y subtemas. Para ello, se empleó el método comparativo constante o el muestreo teórico de la teoría fundamentada (Strauss y Corbin, 1990), si bien, más que una expli- 
cación, lo que se busca es la emergencia de significados desde los datos y una organización de éstos.

Para la presentación, se optó por una clasificación simple de tendencias, como se dijo, y se decidió mostrar algunos puntos considerados importantes en los discursos de los intelectuales; a veces se incluyeron citas que exponen perspectivas y prospectivas cruciales para dar respuesta a las preguntas que guían la investigación y al propósito de pensar y reflexionar juntos sobre el tema.

\section{Algo sobre la conceptualización}

En cuanto al ámbito conceptual, se clasificaron las ideas y opiniones según dos grandes enfoques y tendencias semánticas, sobre todo en la línea del riesgo: el primer grupo abarca lo considerado opresor, distópico, pesimista, negativo, teñido por el miedo; el segundo, la oportunidad de construir una utopía, lo liberador, positivo, optimista, esperanzador, con la pátina del amor. No obstante, cabe aclarar que hay grandes diferencias y muchos matices en la información recabada. ${ }^{2}$ Por ejemplo, Bringel y Pleyers (2020) hablan del debate intelectual y político entre el corona-optimismo y el corona-pesimismo, ${ }^{3}$ pero también hay quien, a pesar de poseer una mirada optimista y propositiva, reconoce que en esta crisis hay riesgos y oportunidades a tener en cuenta (Esteva, 2020). Ante una misma situación, las miradas y voces son múltiples, como se verá. ${ }^{4}$

Dichas tendencias, sobre todo lo prospectivo utópico o distópico, se subdividen, a su vez, en temáticas que se identificaron durante el análisis, tales como economía, ecología, sociedad, cultura, política, tecnología, co-

2 Aclaramos que esta clasificación se realiza según las tendencias semánticas halladas; no por ello se ignora que la esperanza puede fundamentarse en ilusiones optimistas vanas o que el riesgo puede estar preñado de incentivos a la acción y ser motor de trasformación.

3 Según estos autores, el optimismo hace referencia a solidaridad, muerte del capitalismo, vivir mejor con menos, reparto equitativo, rearticulación local, sujetos colectivos; mientras que el pesimismo se identifica con egoísmo, utilitarismo, más control social, restricción de libertades, deterioro de condiciones de vida. También señalan las batallas por futuros alternativos y los desafíos al pensamiento crítico, así como, la narrativa del miedo apocalíptica y la narrativa de la esperanza (Bringel y Pleyers, 2020).

4 Tanto que, incluso, nos preguntamos si estamos realmente ante la misma situación y en el mismo planeta. También espero no distorsionar dichas perspectivas con mis propias ideas, imposibles de eliminar, no siempre fáciles de apartar, porque "quien busca encuentra" y, no nos engañemos, encontramos lo que buscamos.

Fernández, A. M. (2021). Pensar juntos: intelectuales, perspectivas y prospectivas de la crisis del 2020. Iberoforum. Revista de Ciencias Sociales, Nueva Epoca, 1(2), 1-36, Artículos, e000169. https://doi.org/10.48102/if.2021.v1.n2.169 Licencia Pública Internacional - CC BY-NC-ND 4.0 
municación. También se persigue el objetivo de apuntar hacia para qué sirve lo que pasa, en el sentido de las lecciones y los aprendizajes adquiridos -si los hay-, como veremos que subrayan varios autores.

Resumiendo, con todo lo anterior se esbozan las tendencias de percepción, opinión, perspectiva, análisis, explicación, comprensión y prospectiva de cada pensador. Se tuvo en cuenta la importancia de la explicación y de la comprensión (Morin, 1999). Las miradas se enuncian con respeto y con la mayor fidelidad al espíritu del discurso original, sin criticar ni juzgar, pues lo que nos interesa es la opinión de cada pensador y que inviten a la reflexión a cada lectora o lector; lo cual no impide que quien escribe realice la clasificación y algún comentario de carácter general; asimismo, en el apartado final, se reflexiona sobre el conjunto de relatos y significados expuestos. ${ }^{5}$

Algo a destacar es la necesidad y oportunidad de leer distintas tendencias políticas y proyectos de sociedad, por lo que se ha intentado que esta revisión sea lo más completa posible y que incluya diversas miradas. Si bien se dice que hay una batalla de las élites globales por el control de la narrativa (Villamor, 2020) -y esto puede aplicar para los grandes medios de comunicación-, no es menos cierto que, en las redes o la academia, aparecen otros discursos alternativos, complementarios o remanentes, como los aquí presentados - reiteramos que, en cuanto al tema sanitario, la mayoría comulga con el relato médico hegemónico-.

Finalmente, para cerrar este apartado introductorio, contextualizaremos brevemente la situación: se parte de que hay algo -virus, enfermedad, declaratoria de pandemia- que crea o agudiza la "crisis" - social, económica, política, sanitaria-, ante la cual sólo hay dos opciones: resistirse o aceptar, pues unas formas de vida se destruyen y otras se crean. Lo que sí se puede hacer es ver cuál es el probable cambio al que la crisis apunta y qué dirección señala: cómo es, de qué clase, hacia dónde, etcétera.

Es posible afirmar que, desde el discurso de las instituciones internacionales, gobierno y medios, hubo una alerta de pandemia que causó "miedo" y cuya función es generar "protección" en lo biológico y sana respuesta respecto a las emociones - aunque, en la cultura y la política, es

5 Reiteramos que la selección de pensadores y pensadoras se realizó según el interés de las reflexiones vertidas - como se dijo-; hay que añadir, también, los motivos de espacio: "No están todos los que son, pero sí son todos los que están". Se ofrecen disculpas por las omisiones importantes e involuntarias, y por la exclusión de las narrativas consideradas no tan destacadas.

Fernández, A. M. (2021). Pensar juntos: intelectuales, perspectivas y prospectivas de la crisis del 2020. Iberoforum. Revista de Ciencias Sociales, Nueva Época, 1(2), 1-36, Artículos, e000169. https://doi.org/10.48102/if.2021.v1.n2.169 Licencia Pública Internacional - CC BY-NC-ND 4.0 
ejercicio de poder y dominación, entre otras cosas-. Lo que también parece claro es que, entre las medidas tomadas, el confinamiento - con diferencias entre los países- sigue un discurso único, una directriz que, además de las razones sanitarias, implica también razones políticas. En todo caso, invitaría a la introspección personal y a la reflexión social; esta última se desarrolla en las siguientes páginas.

\section{Visiones y relatos de la crisis: riesgos/distopías y oportunidades/utopías}

La pandemia "ha causado una ruptura de las formas habituales de vivir y de hacer las cosas, propiciando un espacio de profunda reflexión colectiva sobre las sociedades que hemos venido construyendo" (Escobar, 2020b, p. 313).

En este artículo se realiza un breve recuento de las inclinaciones, divididas en dos grupos: uno versa sobre el riesgo, la distopía, el pesimismo y el temor; el otro, relativo a la oportunidad, la utopía, el optimismo, la esperanza. Son opiniones o reflexiones de algunos pensadores actuales. Se debe advertir que hay varios textos que presentan ambos aspectos; no obstante, se eligió el considerado predominante al momento de clasificarlos -sin obviar las otras opiniones también recogidas-. Otras narrativas son difíciles de tipificar, pues a una persona le pueden parecer esperanzadoras y otra puede interpretar lo mismo como desolación - como la propuesta de Zizek o de Harari, que se verán a continuación-. Finalmente, hay textos que surgieron en los primeros días y otros que se publicaron después de unos meses de iniciada la pandemia, lo cual también contribuye a una menor o mayor reflexión.

Debemos reiterar que no todos los autores abordan los subtemas aquí seleccionados -identificados tras la primera lectura de los textos-y, sobre todo, que se trata, en casi todos los casos, de consideraciones y opiniones según sus ideologías políticas y conocimientos teóricos profesionales previos; lo reunido aquí no son investigaciones objetivas, amplias y profundas de la contingencia. Constituyen también una suerte de autobservación de las ciencias sociales diversas y divergentes, esto es, de los discursos que las encarnan.

Es justo iniciar la revisión con la polémica que dio la vuelta al mundo en los primeros días de la pandemia: el libro La sopa de Wuhan -recopilación de artículos publicados en la prensa por varios autores y autoras-, ya que muchas personas que escribieron después sobre el tema lo citaron en repetidas ocasiones. En particular, es interesante el contraste entre las 
propuestas de Zizek y Han, que dio lugar a un amplio debate: desde airadas discusiones académicas hasta divertidos memes sobre su diametral consideración de lo que la pandemia nos dejará.

Las sociedades de las oportunidades-utopía-optimismoesperanza

\section{Slavoj Zizek}

Polémico como siempre, esboza una prospectiva futura de cambio que podemos calificar de positiva, pues sostiene que un virus que lleva a pensar una sociedad alternativa es benéfico para el mundo.

\section{Economía}

Parece que algunos medios priorizan el nerviosismo de los mercados antes que la salud, según su óptica. Lo que propone es una reorganización de la economía global y limitar la soberanía de los Estados. La epidemia es un ataque al capital global para el cambio radical necesario: le ha dado un golpe mortal al capitalismo y llegó la hora del comunismo (Zizek, 2020b).

\section{Política}

Las noticias falsas son el virus ideológico que alberga desde racismo hasta teorías de la conspiración, entre otras cosas, para cerrar fronteras. Hay otro virus ideológico que beneficia y que, con suerte, infectará al mundo; según sus palabras, éste es "el virus de pensar una sociedad alternativa, una sociedad más allá del estado nacional, una sociedad que se actualiza a sí misma en las formas de solidaridad y cooperación global" (Zizek, 2020a, p. 22). Según su opinión, la OMS, advierte, de forma precisa y sin pánico, debería tener más poder ejecutivo. Nos une la solidaridad global; podría haber otras catástrofes, como sequías, calor, tormentas, pero la respuesta es una eficiente coordinación global. Reivindica el comunismo basado en la solidaridad y la confianza en las personas y en la ciencia (Zizek, 2020b).

\section{Boaventura de Sousa Santos}

Muestra optimismo; ve la crisis como una oportunidad para mejorar el estado de las cosas, incluso como una lección -cuestión que, como se verá, es compartida por otros autores-. Sin embargo, reconoce el "miedo caótico generalizado y la muerte sin fronteras causada por un enemigo invisible" 
(de Sousa Santos, 2020, p. 32). Acusa a los intelectuales de "Escribir sobre el mundo, pero no con el mundo" (de Sousa Santos, 2020, p. 38) y añade que ya no hay intelectuales de vanguardia sino de retaguardia.

\section{Política}

Considera que la crisis "crea una conciencia de comunión planetaria, de alguna manera democrática" (de Sousa Santos, 2020, p. 23). Sin embargo, su libro también señala que China, con represión y vigilancia, ha ejecutado medidas efectivas.

\section{Economía}

Se agravará la crisis mundial, la pobreza aumentará y, en ausencia de alternativas, ocurrirán nuevas pandemias y futuras cuarentenas. La pandemia también ofrece, según su texto, la posibilidad de quedarse en casa, leer un libro, pasar más tiempo con los niños, consumir menos, prescindir de pasear por los centros comerciales. La pandemia y la cuarentena propician la revelación de formas alternativas de vivir, producir, consumir y convivir. No ignora que la cuarentena es más difícil para las mujeres "cuidadoras del mundo", los ancianos, los vendedores ambulantes, los trabajadores precarizados, informales o autónomos, etcétera, y que la vuelta a la normalidad no será igual de fácil para todos (de Sousa Santos, 2020).

\section{Ecología}

Señala como positivo la "disminución de la contaminación atmosférica" (de Sousa Santos, 2020, p. 23), frente a la crisis ecológica grave e irreversible que existe.

\section{Pedagogía}

En su obra, destaca la pedagogía del virus y sus lecciones: 1 . Pandemia castigo por la violación de la naturaleza y la crisis ecológica. 2. No discrimina en la muerte; sí según la vulnerabilidad de la gente. 3. Capitalismo neoliberal sin futuro por la crisis humanitaria; habrá más pandemias si la política neoliberal socaba la capacidad de respuesta del Estado. 4. Extrema derecha y derecha neoliberal desacreditadas por su darwinismo social; fracaso del gobierno de izquierda, rendido al catecismo neoliberal. 5. Colonialismo y patriarcalismo se fortalecen en tiempos de crisis, y los países pobres sufren 
más. 6. Se regresará al Estado y la comunidad; el capitalismo le impidió al Estado responder a la emergencia (de Sousa Santos, 2020).

Finalmente, "La nueva articulación presupone un giro epistémico, cultural e ideológico que respalda las soluciones políticas, económicas y sociales que garanticen la continuidad de la vida humana y digna en el planeta" (de Sousa Santos, 2020, p. 84). Palabras que hablan de nuevas epistemologías - otros autores también lo mencionan- y que significan una mirada optimista ante la idea de una mejor vida.

\section{Edgar Morin}

Afirma que la respuesta a la crisis que afecta la interdependencia mundial sólo puede ser planetaria.

\section{Economía y ecología}

"El virus está trayendo una nueva crisis planetaria a la crisis planetaria de la humanidad en la era de la globalización" (Morin, 2020, p. 1). "La perturbación económica causada por la epidemia fomenta su propagación" (Morin, 2020, p. 1), por lo que se trata de una crisis de la economía mundial que beneficiará a la ecología. El coronavirus hace mucho daño, pero descubre verdades esenciales: "El virus nos dice entonces que esta interdependencia debe dar lugar a la solidaridad humana en la conciencia de nuestro destino común" (Morin, 2020, p. 1).

\section{Jeremy Rifkin}

Parte de que estamos ante la tercera revolución industrial y "Nos enfrentamos a la sexta extinción y la gente ni siquiera lo sabe" (Rifkin, 2020, p. 1). Al respecto, afirma que los científicos dicen que en ocho décadas desaparecerá la mitad de los humanos y animales. No obstante, ante este panorama, afirma tener confianza en la generación millennial para revertir la situación. Así que hay riesgo y oportunidad (Rifkin, 2020).

\section{Ecología}

"La actividad humana ha generado estas pandemias porque hemos alterado el ciclo del agua y del ecosistema que mantiene el equilibrio en el planeta" (Rifkin, 2020, p. 1). La elevación de la temperatura, el suelo arruinado, todo traerá más pandemias y desastres. Hay que ir hacia la Green New Deal global y pensar en la glocalización (Rifkin, 2020). 


\section{Economía y política}

Estamos en la tercera revolución industrial, en la cual la comunicación por internet y el internet de las cosas aportan conocimiento, energía y movilidad. ${ }^{6}$ Confía en que la progresión demográfica se va a terminar porque las mujeres más autónomas tenderán a tener menos hijos. Propone eliminar fronteras y prejuicios que separan a la humanidad (Rifkin, 2020).

\section{Michel Maffesoli}

Proclama el fin de una civilización y el renacimiento de otra mejor.

\section{Política}

"El fin de un mundo que se manifiesta, a diario, en la degeneración intelectual, política y social" (Maffesoli, 2020, p. 1). La élite está paranoica y la pandemia "es el símbolo del fin del optimismo en el progresismo moderno" (Maffesoli, 2020, p. 1). El orden de las cosas -individualismo, materialismo, globalización, mercado sin límites- llegó a su fin y emergen los valores de la solidaridad y el "ideal comunitario". Añade que, "Así como la crisis de salud que trae la muerte individual es una indicción de la crisis de civilización" (Maffesoli, 2020, p. 1), el ser-junto, el ser-con, la sociedad visible y lo espiritual invisible ocuparán un lugar de preferencia.

\section{Bruno Latour}

Observa dos tendencias: una es que regresemos a un peor escenario; la otra, por la que parece decantarse, es la oportunidad positiva del momento.

\section{Ecología}

Considera que es la ocasión ideal, una oportunidad, para no retomar la vida de antes y mejorar la calidad de vida ecológica: "resocializar a billones de humanos, ¡los microbios son entonces los mejores globalizadores!" (Latour, 2020, p. 2).

\section{Economía}

Dice que los globalizadores buscan liberarse del estado de bienestar, desarrollar una red de seguridad para pobres, reglamentar en contra de la contaminación, deshacerse de la gente que atiborra el planeta; según él,

6 Como dato curioso, cabe mencionar que no escribe en computadora. 
esto significa más de lo mismo, pero más grave. Por ello, propone que "No se trata tampoco de retomar o modificar un sistema de producción, sino de renunciar a la producción como principio fundamental de nuestra relación con el mundo" (Latour, 2020, p. 4), por lo que hay que tomar medidas protectoras que impidan regresar a lo mismo o que empeore, reitera. Además, considera que el confinamiento ha servido para descubrir a qué estamos apegados y de qué estamos dispuestos a liberarnos (Latour, 2020).

\section{Atilio Borón}

El virus desatado refleja el tipo de sociedad y economía que surgirá; una oportunidad de crecer el Estado y disminuir el mercado.

\section{Economía}

La primera víctima de la pandemia fue el neoliberalismo. Reclama una sociedad futura con un Estado que controle el mercado: el mundo post pandémico lo dibuja con más Estado y menos mercado. China será el mercado de la economía mundial y Estados Unidos enfrentará su declive (Borón, 2020).

También habla del cruel dilema entre la salud de la población y el vigor de la economía. No quiere que el mundo vuelva a ser como antes. Sostiene que hay un "Tremendo desafío para quienes queremos construir un mundo post capitalista porque, sin duda, la pandemia y sus devastadores efectos ofrecen la oportunidad única, inesperada, que sería imperdonable desaprovechar" (Borón, 2020, p. 6). Incluso invita a luchar hasta el fin, como dijo Fidel.

\section{Yuval Noah Harari}

"La gran tormenta económica todavía está por venir" (Harari, 2020b, p. 1), pero hay que confiar en la ciencia ${ }^{7}$ y en la cooperación internacional. Hay que mantener el distanciamiento social, pues el virus explota los nobles instintos sociales (Harari, 2020a). Enfatiza, sobre todo, la necesaria confianza en la política. Su mensaje ofrece claroscuros sobre riesgos y oportunidades, mirada pesimista y optimista ante lo que acontece y el futuro, pero prevalece cierta confianza en el porvenir si se mantienen las institu-

7 Donó un millón de dólares a la OMS. 
ciones y se sigue los dictados de la ciencia, como ya apuntaba en su producción anterior (Harari, 2013, 2015).

\section{Política}

Afirma que, más que el virus, le atemorizan los demonios que agitan el alma de la humanidad: el odio, la codicia, la ignorancia. Si la gente le achaca a los extranjeros y a las minorías la responsabilidad de la epidemia, si las empresas ávidas de ganancias sólo se preocupan por obtener beneficios y si damos crédito a toda suerte de teorías conspiranoicas, será mucho más difícil vencer al virus y tendremos que vivir después en un mundo envenenado por ese odio, esa codicia y esa ignorancia (Harari, 2020b, p. 2).

No se trata de elegir entre solidaridad internacional y aislamiento nacionalista - dictadura-, sino que se puede optar por la cooperación internacional -como se mencionó con anterioridad-. Para él, los dirigentes autoritarios y populistas obstaculizan la libre circulación de información y minan la confianza de la opinión pública en la ciencia. Considera que las instituciones independientes sólidas han combatido más eficazmente el virus que las dictaduras despóticas. A lo cual, añade que los instrumentos de vigilancia desplegados tienen mentalidad de soldados y que se necesitan enfermeras, no militares (Harari, 2020b).

Hay un descrédito y desconfianza en las instituciones -y la confianza es el motor del sistema político-; también se ha minado la confianza en los medios, autoridades y academia. Si la confianza en las instituciones desaparece, el mundo se desplomará y la civilización se vendrá abajo (Harari, 2020b).

\section{Economía}

A la frase inicial de la aguda crisis económica que se avecina, se une el endeudamiento de los gobiernos para distribuir a la población (Harari, 2020c).

\section{Ecología}

"Nos esperan cosas muchísimo peores que la COVID-19 si no tratamos el problema medio ambiental" (Harari, 2020c, p. 1). ${ }^{8}$

8 Es una epidemia leve que procede del murciélago, afirma. 


\section{Ciencia y tecnología}

"Hoy en día contamos con los conocimientos científicos e instrumentos tecnológicos requeridos para vencer la actual pandemia" (Harari, 2020b, p. 1). Considera que China ya identificó y secuenció el virus; pese a que no hay cura, existe la vacuna, aunque sólo será para los países ricos, sentencia.

\section{Judith Butler}

El virus no discrimina: demuestra la frágil humanidad (Butler, 2020a). Más que optimista, su discurso es negativo, pero hace un llamamiento final a unir al mundo en el deseo colectivo radical y de solidaridad entre países; el "deseo de rehacer el mundo" (Butler, 2020b, p. 1).

\section{Ecología}

"Soy asmática y pude respirar en abril de una forma que nunca había podido" (Butler, 2020b, p. 1). Hay que corregir los impactos sobre el clima, la destrucción de la biodiversidad biológica y la invasión de diversos ecosistemas.

\section{Economía}

"La salud de la economía sacrifica la salud de los cuerpos de las minorías" (Butler, 2020b, p. 1). La libertad lleva a la enfermedad, en el sentido de que el peligro está en confundir la libertad individual con la invisibilización de las muertes potenciales y reales. Se trata de "Un capitalismo que considera desechables las vidas de los trabajadores" (Butler, 2020c, p. 1), quienes crean la salud económica, por lo que hay que mejorar la salud de la población. Se pone en peligro la vida de las personas pobres, ante la supremacía blanca; se violenta a mujeres, queers y trans.

\section{Política}

"No hay un futuro utópico que vaya a desarrollarse automáticamente, va a depender de las prácticas humanas y de la habilidad que tengamos para intervenir en el mundo político y económico" (Butler, 2020b, p. 1). Llama a crear un acuerdo colectivo y renovar la igualdad social y económica, a cuidar el contexto climático, deshacer el prejuicio local y nacionalista, y a crear nuevas condiciones de vivir y desear. 


\section{Arturo Escobar}

Afirma que se decía que el capitalismo no podía pararse y se paró, por lo que hay que aprovechar la oportunidad y proponer un nuevo proyecto humano y planetario: "En medio de este terrible desespero, nos ofrece la oportunidad de recuperar la máquina infernal que nos hemos construido" (Escobar, 2020a, p. 31), pues la pandemia es un llamado de alerta que nos permite ver los aspectos del horror que consideramos normal -y que es anormal-.

\section{Economía y ecología}

Es momento de pensar cómo se reestructura el capitalismo ante la crisis económica. Así como de ver la pandemia como una crisis civilizatoria, desbalance económico, debacle ambiental, cambio climático, 5G contra los discursos de sustentabilidad (Escobar, 2020b).

\section{Política}

"La crisis nos convoca a considerar que lo que está en juego es un nuevo proyecto histórico de sociedad, así como un modelo de vida diferente, que nos permita reaprender co-existir con nuestros congéneres y con todos los seres vivos de forma mutuamente enriquecedora" (Escobar, 2020b, p. 314). Habla de las covid-narrativas como estrategias para las transiciones: re-comunalización de la vida social; re-localización de los actores sociales, productivos y culturales; fortalecer autonomías; despatriarcalización, desracialización y descolonización de las relaciones; liberación de la madre tierra, y construir alternativas y mundos nuevos desde abajo autónomamente (Escobar, 2020b).

En resumen, es una oportunidad ontoepistémica para la relacionalidad e interdependencia, para dar lugar a la biología del amor como fundamento de la vida. La propuesta es "evitar volver a la normalidad" e "interrumpir el proyecto globalizador de meter por la fuerza a todos los mundos en uno solo" (capitalista, heteropatriarcal, globalizado), para fomentar, en cambio, el pluriuniverso (Escobar, 2020a, p. 51).

\section{Noam Chomsky}

Es un momento histórico, "confluencia de crisis existenciales" (Chomsky, 2020b), medioambientales, guerra nuclear, deterioro democrático y pandemia; "nos enfrentamos a algo así como la peste negra del siglo XIV" (Chomsky, 2020a, p. 1). Pese a su análisis negativo, concluye que "ese no es 
el mundo que queremos" (Chomsky, 2020b), dejando avizorar la oportunidad de un mejor futuro.

\section{Economía y política}

La lección: "otro fallo masivo y colosal de la versión neoliberal del capitalismo" (Chomsky, 2020a). Si no se aprende, la próxima vez será peor. Añade que los gobiernos están "siendo el problema y no la solución" (Chomsky, 2020a). Los científicos sabían que vendrían pandemias y no se prepararon; ni las farmacéuticas ni los gobiernos. Sólo Cuba ha sido un ejemplo de internacionalismo; aunque hay esperanza con Sanders ${ }^{9}$ en Estados Unidos tras la crisis agravada por el sociópata de Trump, añade (Chomsky, 2020a, p. 1).

\section{John Harvey}

Propone transformaciones que pasan por una socialización de la sociedad; el panorama es negativo, pero parece anunciar el cambio (Harvey, 2020).

\section{Economía, ecología y política}

Se avecina un gran problema económico: el desembarco de la inteligencia artificial, desempleo, recesión. Las farmacéuticas no invierten en prevención; están más interesadas en la enfermedad y en el dinero. Se necesitará socializar la economía sin llamarlo socialismo. El consumismo será el de atracón tipo Netflix. Habrá cambios en el consumo, como menos viajes, para salvaguardar la calidad del aire. Los países menos neoliberales y China gestionaron mejor la pandemia. Tendrá que haber cambios políticos de envergadura (Harvey, 2020).

\section{Gilles Lipovetsky}

Afirma que, tal vez, al final de la crisis, el mundo no habrá cambiado -o no tanto- (Lipovetsky, 2020a), incluso se acelerarán algunas tendencias actuales. También señala que "Los hombres han encontrado una y otra vez nuevas soluciones a los problemas encontrados" (Lipovetsky, 2020b, p. 1). Es difícil clasificar su postura; sin embargo, según su propio relato, parece más una oportunidad, una mirada positiva - en tanto que la crisis se superará- sobre el devenir del mundo.

9 Se escribió antes de que el candidato fuera Biden. 


\section{Economía}

El capitalismo ha creado el problema: no hay ultra pobres, pero sí marginados; de ahí el éxito del populismo. Enfrentamos problemas sanitarios por falta de presupuesto. Hay que cuestionar la globalización ultraliberal y exigirle más al Estado (Lipovetsky, 2020b).

\section{Política}

Hay un movimiento de desconfianza hacia las autoridades por los errores cometidos. No obstante, la gente acata las medidas responsablemente, afirma. Respecto a los ataques a la libertad que se den en el marco de la protección, dice que la vida se antepone a la libertad, pero que luego se recuperará esta última (Lipovetsky, 2020c).

De alguna manera señala que, al acabar la crisis, nada va a cambiar; está consciente de que algunos auguran un tsunami que cambiará todo; él dice que no sólo no habrá cambio, sino que se acelerarán las tendencias actuales. Esto es, tras el encierro, la gente necesitará airearse, tener vacaciones, hacer compras, ver series; "es lo que hay", añade (Lipovetsky, 2020b, p. 1). El ocio y el turismo retornarán de la mano del capitalismo de la seducción (Lipovetsky, 2020a, 2020b).

Añade que Europa no está protegida contra las grandes epidemias. También afirma: "Creo en la ciencia. Estoy luchando contra los movimientos antivacunas" (Lipovetsky, 2020, p. 1)..$^{10}$ En este sentido, vaticina: "Sabemos que este periodo durará aproximadamente dos años, no más porque ya hay vacunas en camino, entonces no hay nada en la cultura que alcanzará a cambiar de fondo" (Lipovetsky, 2020c, p. 1). No cambiará la forma de sentir y desear; cambiará la orientación de los Estados y la política. No obstante, reiteramos, su postura es una de las más difíciles de clasificar.

\section{Maristella Svampa}

Dos caminos se avizoran: por un lado, la globalización neoliberal autoritaria con vigilancia digital; por el otro, la posibilidad de edificar la globalización democrática con paradigma ciudadano y un "nuevo pacto ecosocial y económico" (Svampa, 2020, p. 27). Se esbozan horizontes posibles y el paradigma del cuidado.

10 Dice que hay que quitarse la mascarilla porque es un peligro, pero que las vacunas acabarán con la pandemia. 


\section{Ecología}

Se ocultan las consecuencias ambientales de la crisis climática y prolifera un discurso bélico para cohesionar en torno al miedo, el cual lleva a la ciudadanía a denunciar al vecino (Svampa, 2020).

\section{Política y economía}

El Estado actúa durante la pandemia como leviatán sanitario y esboza dos rostros: ayudar y declarar el estado de excepción. La crisis de la pandemia ofrece un aprendizaje al poner de manifiesto la desigualdad social y la concentración de la riqueza; también emergen partidos de derecha autoritaria, producto de la xenofobia y el antiglobalismo. Ante este panorama, la encrucijada civilizatoria puede avanzar hacia la globalización neoliberal autoritaria con vigilancia digital y sobre el modelo asiático sofisticado, o hacia el "capitalismo del caos" en la periferia; sin embargo, también puede ir en la dirección de la construcción globalizada democrática, bajo un paradigma democrático y ciudadano, con pactos de justicia social y ambiental (Svampa, 2020).

Sobresale la idea de que la crisis genera procesos de "liberación cognitiva", la cual transforma la conciencia, supera el fatalismo, torna posible lo que era inimaginable; una oportunidad de transformación para mejorar la vida en medio del desastre, en la cual la instauración del paradigma del cuidado es importante, así como el gran pacto ecosocial y económico a escala nacional y global (Svampa, 2020).

\section{Claudio Esteva}

Considera que, a pesar de las voces que señalan que no hay futuro, se está ante una nueva correlación de fuerzas. Invita a rechazar los "cachondeos apocalípticos", como los discursos de organismos internacionales -incluso de presidentes de gobiernos que siembran el pánico-, así como a reconocer que "el mundo que conocíamos llegó a su fin y no volverá" (Esteva, 2020, p. 57).

\section{Política}

Se está ante fuerzas oscuras: la sociedad de control de los medios electrónicos que pretenden someter los pensamientos, comportamientos, así como imponer el estado de excepción. Parafraseando a de Sousa Santos, afirma que "se está desmantelando democráticamente la democracia" y asoma, 
como decía Foucault, "el fascista que todos llevamos dentro" (Esteva, 2020, p. 58), además de la posibilidad del estado tecnototalitario perfecto, según Agamben o Zibechi - cuando habla de fascismo y tecnologías de control-.

Sin embargo, se está ante la oportunidad de "recuperar el sentido y los sentidos por el inevitable arraigamiento a lo local" (Esteva, 2020, p. 59); esto es, restablecer la importancia de lo local y de las personas reales, personas que den un nuevo sentido a sus vidas; "se está produciendo un despertar" (Esteva, 2020, p. 59). La pandemia significa una llamada de alerta ante un discurso "progresista" -ecologismo global peligroso, medicina institucional que amenaza la salud- con un lenguaje obsoleto y una mirada fuera de lugar. Debemos regresar a los lugares y las personas concretas que nos rodean, utilizar nuevos ojos para el reconocimiento de otro yo; no como individuos de una masa homogénea, sino como un nudo en un tejido de relaciones concretas; recuperando la mirada propia. "No queremos volver a la normalidad" es uno de los lemas del momento. Propone "Defender la vida y el territorio" y "volver a ser lo que somos" (Esteva, 2020, p. 66).

$\diamond$

Con aires globalistas y de solidaridad, diferencias acerca del papel del Estado y del mercado, la necesidad del cuidado ecológico, la amenaza de que la próxima vez será peor y el deseo de la lección aprendida, además de un reconocimiento al gobierno de China... Así llegamos al segundo grupo: coincidentes o no en visiones y narrativas, disidentes en cuanto a la dirección de los acontecimientos futuros. Como veremos a continuación, algunos de estos autores también coinciden con ciertos puntos del enfoque anterior.

\section{Las sociedades del riesgo-distopía-pesimismo-temor}

\section{Giorgio Agamben}

Tiene una de las posturas más pesimistas: desde las causas del virus hasta los aspectos y las consecuencias de la pandemia. También fue una de las primeras voces públicas en pronunciarse sobre lo que pasaba y lo que se avecinaba desde una mirada biopolítica. 


\section{Política}

"El temor de contagiarse de otro, como otra forma de restringir libertades" (Agamben, 2020a, p. 7). Considera las medidas y el estado de excepción como irracional e injustificado - compara la COVID-19 con la gripe-, convocado con el pretexto del miedo: "La limitación de la libertad impuesta por el gobierno es aceptada en nombre de un deseo de seguridad que ha sido inducido por los mismos gobiernos que ahora intervienen para satisfacerla" (Agamben, 2020a, p. 21). Así, se considera a todos "contagiadores"; lo más grave, además de la limitación de libertades, es la degeneración de la relación humana: "Nuestro prójimo ha sido abolido" (Agamben, 2020a, p. 33). La gente acepta y luego se pregunta si la forma en la que vivían era la correcta. La ciencia - como la religión, añade- puede producir superstición y miedo, o puede ser usada para difundirlos: "El miedo [...] hace aparecer [...] que nuestra sociedad no cree en nada sino en la nuda vida" (Agamben, 2020b, p. 254); las personas están dispuestas a sacrificar todo: condiciones de vida, relaciones, trabajo, amistad, afectos, religión, política... para no enfermarse, por lo que se borra al prójimo - como ya se dijo en el texto anterior-.

En resumen, se ha sacrificado la libertad por la seguridad; la sociedad está condenada al miedo y la inseguridad. Se equipara el miedo con una guerra; la ciencia es la nueva religión o la religión de la salud, y la "bioseguridad" es el "paradigma de la seguridad", el nuevo dispositivo; tras la guerra, la herencia de la tecnología avanza: las máquinas sustituyen a los humanos, el contacto - contagio- entre seres. Así que auspicia un futuro sin libertades, con el estado de excepción más eficaz de la historia, sumamente tecnologizado - por ejemplo, con la celulización coercitiva de toda la población- y deshumanizado (Agamben, 2020c).

\section{Byung-Chul Han ${ }^{11}$}

Considera que todo lleva hacia una sociedad totalitaria de vigilancia virtual según el modelo chino. Si bien, en algún momento, añade con tenue esperanza: "Confiemos en que tras el virus venga una revolución de la humanidad" (Han, 2020a, p. 1). Enfatiza la necesidad de salvar al planeta. Así, su mirada es pesimista a corto plazo -lo que es habitual en su obra-, como consecuencia de la pandemia.

11 Sí desea llevar mascarilla, pero no se encuentran a la venta, aclara.

Fernández, A. M. (2021). Pensar juntos: intelectuales, perspectivas y prospectivas de la crisis del 2020. Iberoforum. Revista de Ciencias Sociales, Nueva Época, 1(2), 1-36, Artículos, e000169. https://doi.org/10.48102/if.2021.v1.n2.169 Licencia Pública Internacional - CC BY-NC-ND 4.0 


\section{Economía}

El crash se hubiera producido sin virus; quizá con él será mayor. El pánico ha sido desproporcionado; ni la gripe española tuvo un efecto tan devastador. El capitalismo seguirá más pujante que nunca. El virus no hace la revolución; al contrario, aísla e individualiza (Han, 2020a).

\section{Política y tecnología}

Asia combatió la pandemia mejor que Europa; por lo tanto, se apostará por la vigilancia digital. El big data también es fundamental para defenderse de la pandemia. En Asia, la combaten no sólo virólogos y epidemiólogos, sino también informáticos y especialistas en macrodatos (Han, 2020a). China venderá su estado policial digital al mundo. La biopolítica digital se acompaña con la psicopolítica digital, la cual controla activamente a las personas (Han, 2020b). La digitalización elimina la realidad. En época de fake news, hay una apatía hacia la realidad (Han, 2020a).

\section{Néstor García Canclini}

Otra visión pesimista que señala que hay que diferenciar entre los deseos de lo que queremos que ocurra tras la pandemia y lo que es razonable esperar, pensar y hacer ahora.

\section{Política}

Habla de desciudadanización y pérdida de derechos ciudadanos, dado que la video política trasladó la formación de opinión pública de las calles a las pantallas: "nuestros comportamientos son grabados y combinados en algoritmos de lo íntimo" (García Canclini, 2020, p. 1). Lo cual se acentuó en la pandemia con las instituciones y aplicaciones; empoderamos a los cuatro gigantes electrónicos - Google, Apple, Facebook y Amazon- con nuestros datos y ahora nos controlan, por lo que el lugar de los ciudadanos en la globalización está diluyéndose (García Canclini, 2020).

\section{Michel Wieviorka}

"Lo mejor será mejor y lo peor será aún peor" (Wieviorka, 2020a, p. 1). Occidente era feliz y no se daba cuenta, afirma. Ahora, habrá una trasformación de ideas y un quiebre ideológico. En todo caso, aboga por "modificar nuestras ideas y nuestros instrumentos para pensar el mundo" (Wieviorka, 2020b); es el momento de responder: ¿qué modelo de desarrollo queremos? 


\section{Política}

Hay ideas, pero faltan líderes, así como confianza en los actores políticos (Wieviorka, 2020a); la desconfianza y la sospecha nos hacen mirar al poder de forma negativa. Hay una descomposición del sistema político, cuyos extremos, según el autor, se rehúsan a la mediación entre una izquierda ecologista y social, de derechos humanos y con menos ideas, y una derecha comprometida con el neoliberalismo y la buena gestión. El poder está desbordado; los sectores de la población -obreros, ancianos, pobres-, olvidados. Es una fase de la modernidad con riesgo y sentido de ausencia de seguridad (Wieviorka, 2020b). A lo cual, se han de sumar las fuerzas de la irracionalidad y los reaccionarios a la ciencia.

Considera positiva la ciencia globalizada, así como el fortalecimiento de los Estados: hacerlos más redistributivos, generar una reindustrialización y promover una mayor intervención política, económica y de políticas públicas.

\section{Tecnología}

"Hemos entrado completamente en el mundo digital" (Wieviorka, 2020b, p. 1); estamos ya inmersos en una nueva cultura ultraconectada: trabajo en casa, educación virtual, comunicación digital. Las ciencias sociales deberían "Ayudar a decidir cuáles son las mejores políticas" (Wieviorka, 2020b, p. 1).

\section{Raúl Zibechi}

Augura la llegada del Nuevo Orden Mundial (NOM) que controlará a la población del planeta (Zibechi, 2020).

\section{Política}

China es el referente del control mundial de la población y, ante el caos creado por la pandemia, será el referente del NOM. Se aceleran los procesos de militarización, el ascenso de China, la decadencia de Estados Unidos, el fin de la globalización neoliberal, el reforzamiento de los Estados, la subida al poder de la ultraderecha y los fascismos, el vaciamiento de las democracias y la desbandada de la Unión Europea. El 5G, la inteligencia artificial, la computación cuántica y los superordenadores serán las señas de identidad tecnológicas.

El autor enfoca el futuro hacia el poder político de los Estados nación -aunque habla del NOM-, a diferencia de los anteriores, que dan un peso más o menos importante a la globalización (Zibechi, 2020). 


\section{Miklos Luckas}

Otra mirada pesimista: direcciona el futuro hacia el imperio de la inteligencia artificial y el transhumanismo; un mundo regido por los algoritmos y el poder de los metacapitalistas - financieros y tecnológicos, que operan más allá de la ley-, más el modelo chino dentro del NOM (Luckas, 2020).

\section{Política y tecnología}

Remarca el papel que tendrá la inteligencia artificial, el monitoreo de la ciudadanía por parte de los gobiernos y las empresas - con buenas intenciones o para ejercer control-. La inteligencia artificial, los algoritmos y el big data ya están en el nivel de sistema de aprendizaje autónomo. Se abolirán los empleos, la privacidad y las libertades; aumentará la censura. Se vigilará y también se predecirá el comportamiento, con lo cual el futuro de la humanidad no pinta muy bien. El cambio en esta crisis es de gran magnitud y dimensión desconocida, pues no lo guía la política o la economía, sino la tecnología (Luckas, 2020).

\section{Agustín Laje}

En sentido similar, apunta hacia la reconfiguración del NOM, con una sociedad burocrática y tecnológica de vigilancia en la cual imperará el autoritarismo (Laje, 2020a).

\section{Economía}

Las consecuencias económicas serán importantes; no habrá fin del capitalismo, sino estados fallidos y estados vigilados. La gente sin ingresos vivirá con la renta mínima, constituyendo clientelas dependientes de los servicios de salud, de los subsidios y del entretenimiento. Además, en el encierro no se puede protestar: está prohibido trabajar y protestar (Laje, 2020a).

\section{Política}

En el ámbito del poder y la política, se podría llegar a la disciplina foucaultiana y al control de la psique, como señala Han (2020a; 2020b). El globalismo es una destrucción planificada por ingenieros sociales. Encerrarse, cubrirse el rostro, desinfectarse, distanciarse, ser responsable, vigilar y denunciar al prójimo equivalen a tener menos vida social; la vida transcurrirá a través de las pantallas. 


\section{Comunicación}

Hace hincapié en que "La pandemia es un hecho, pero también una narrativa. Dominar el virus ha insumido la mitad de los esfuerzos globales: la otra mitad se abocó a dominar el relato sobre el virus" (Laje, 2020b, p. 17). Todo empieza con un murciélago y acaba con una vacuna. Se presenta como utopía la "nueva normalidad" y el "reseteo"; este último es el sueño de la revolución de la "deconstrucción". Otra cura sería la "restauración", que es "devolver a nuestras vidas todo lo valioso que nos fue arrebatado en las últimas décadas" (Laje, 2020b, p. 20).

Como se observa, en casi todos los relatos de este grupo hay, más o menos, un gran pesimismo. Si bien las propuestas de Agamben y Zibechi, por ejemplo, son diferentes de las de Luckas y Laje - porque parten de posturas ideológicas distintas-, coinciden en el rechazo del totalitarismo global digital; así, posiciones que pueden nombrarse socialistas y conservadoras afirman querer defender la democracia y la vida humana.

\section{Consideraciones y reflexiones finales}

El problema con el mundo es que los estúpidos están seguros de todo y los inteligentes están llenos de dudas.

Beltrand Russell

\section{Percepciones y propuestas}

Tal vez, entre la prospectiva del comunismo solidario global y la del control digital autoritario global - por citar dos de las primeras propuestas que vieron la luz a raíz de la publicación de los textos de Zizek y Han, que tanto debate han suscitado-, hay otros caminos en el horizonte, alejados de la globalización. Los dos extremos mencionados hablan sobre utopías y distopías, solidaridad e individualismo, comunismo y capitalismo, pero todo planetario. No obstante, también hay propuestas sustentadas en lo local e incluso en el Estado nación; propuestas que emanan desde lo que antaño fueran la derecha y la izquierda.

Se espera que este repaso de ideas sirva para reflexionar entre todos y todas; que invite también a la introspección, no sólo en el ámbito personal, sino en el discurso de la dimensión social y en el trabajo de la inves- 
tigación académica. Esto, en el sentido de que todos hablan de un cambio de paradigma (Kuhn, 1986) y, al parecer, el mundo, las instituciones internacionales, los gobiernos y parte de los intelectuales parecen sumidos en las consideraciones de siempre y en el viejo modelo de pensamiento. En un mundo que, a ratos, se antoja que va a desaparecer pronto; en otras ocasiones, que va a continuar igual - como señala Lipovetsky (2020)-, o, en otros casos, que nunca existió y que sólo imaginamos, que vivimos en una ilusión, pues hay quien dice que, más que inventar, descubrimos.

Como se observa, en general, varios intelectuales abogan por una transición hacia un mundo diferente del conocido (Wallerstein, 1998), con el final del capitalismo tal como se conoce en nuestros días, el final de un ciclo (Niño-Becerra, 2020), la posibilidad de una suerte de metacapitalismo (Luckas, 2020), el globalismo (Vidal, 2020) y la dictadura tecnodigital total (Han, 2020a); sin embargo, hay otra mirada que pronostica una sociedad más justa económica, social, ecológica y humanamente (Escobar, 2020b; Svampa, 2020; Esteva, 2020). En todo caso, no hay duda de que "Cuando esto termine la vida ya no será igual" (Ramonet, 2020, p. 1), para bien o para mal.

Ello, sin olvidar las propuestas del Foro Económico Mundial sobre el gran reinicio o gran reseteo, ${ }^{12}$ que habla sobre la oportunidad de oro que nos ofrece la crisis para eliminar fronteras y darnos cuenta de la interdependencia del planeta a favor de la resiliencia, de un mundo inclusivo y sostenible, a modo de nuevo pacto social o nuevo orden mundial; una cuarta revolución industrial (Schwab y Malleret, 2020; World Economic Foro, 2020; Mercola, 2020). ${ }^{13}$

\section{Ortodoxias y disrupciones}

Para empezar, entre los intelectuales, casi ninguno -a excepción de Agamben (2020a) - pone en duda la narrativa única y oficial del virus y las medidas sanitarias; algunos lo relativizan y contextualizan históricamente - como Harari (2020c) - o condicionan su grado de peligrosidad como estrategia mediática -como Luckas (2020) - , si bien en las ramas médicas no alópatas e incluso alópatas hay algunas discrepancias notables -lo cual

12 Hay polémica sobre la traducción.

13 Un amplio, profundo e interesante debate que no es posible incluir en estas páginas, dado que rebasa los objetivos del artículo.

Fernández, A. M. (2021). Pensar juntos: intelectuales, perspectivas y prospectivas de la crisis del 2020. Iberoforum. Revista de Ciencias Sociales, Nueva Epoca, 1(2), 1-36, Artículos, e000169. https://doi.org/10.48102/if.2021.v1.n2.169 Licencia Pública Internacional - CC BY-NC-ND 4.0 
no puede ser de otra manera si creemos en una ciencia viva y dinámica, al servicio de la vida-. También es cierto que los autores citados no son especialistas en medicina y sería pretensioso opinar sobre esa esfera, la cual tampoco es el objeto de estas páginas. Sin embargo, sí es necesario remarcar cómo varios reiteran su total confianza en la ciencia.

Como curiosidad, cabe apuntar el protagonismo de un virus que habla, da lecciones y une a la humanidad - como se lee en algunos textos y más adelante se especifica-, frente al discurso del virus letal que hay que atacar como si se tratara de un enemigo en una guerra -como leemos en los discursos de algunos gobiernos-. Se vislumbra la pedagogía frente al belicismo lingüístico.

Lo que sí sorprende es la coincidencia y la discordancia de las narrativas, lo cual se agradece en un momento de pensamiento y relato único oficial; no obstante, ciertamente, al leerlas, se antoja pensar si describen distintos planos de realidad y analizan problemas diferentes. Así que, no sólo no se ha acabado la historia -como Fukuyama (1992) predijo-, ${ }^{14}$ sino que tampoco se ha muerto el relato único -como anunció Lyotard (2000)- . Esto último se comprueba hoy en los medios, gobiernos nacionales y organismos internacionales: todavía hay apertura y diversidad de criterios en la intelectualidad, como se ha visto. ${ }^{15}$

También se debe mencionar el llamado insistente a confiar en la ciencia por parte de la mayoría (Badiou, 2020), con pocas excepciones (Agamben, 2020a); sin embargo, no queda claro si se trata de la ciencia como duda y verdad dinámica, o del cientificismo como ideología y creencia. ${ }^{16}$

Asimismo, es posible señalar que algunos consideran el virus un maestro y la pandemia una lección en varios sentidos, especialmente por la necesidad de cambiar la sociedad y mejorar la vida humana y del planeta. En concreto, de Sousa Santos (2020) alude a la lección, así como Chomsky

14 No triunfó el modelo del liberalismo político y económico de occidente, ni la tristeza, pero tal vez ahora, ante la amenaza globalista tecnodigital, sí se acabe la historia de otra manera y con miedo, como muestran algunos relatos aquí presentados.

15 Por supuesto, los primeros se centran en el relato oficial de un virus peligroso y las medidas a tomar, además de ir lanzando conceptos e ideas sobre el futuro. Mientras que los segundos tienen un enfoque multicausal de la pandemia y despliegan posibles desarrollos societales futuros; algo que se agradece, como se dijo, pues airea, renueva y aligera la mente en estos días.

16 Desafortunadamente, éste es un tema que desborda el objetivo de este texto.

Fernández, A. M. (2021). Pensar juntos: intelectuales, perspectivas y prospectivas de la crisis del 2020. Iberoforum. Revista de Ciencias Sociales, Nueva Epoca, 1(2), 1-36, Artículos, e000169. https://doi.org/10.48102/if.2021.v1.n2.169 Licencia Pública Internacional - CC BY-NC-ND 4.0 
(2020a, 2020b); Svampa (2020) propugna la oportunidad de generar aprendizaje en medio de la crisis. El virus dice, según Morin (2011); el virus sabe, afirma Harari (2020b); lo que dota de personalidad e incluso inteligencia al susodicho.

Por otra parte, algunos autores amenazan que la próxima vez será peor; es el caso de Harari (2020c), Chomsky (2020a, 2020b), Morin (2011) y de Sousa Santos (2020), si bien los dos primeros discrepan sobre la gravedad del coronavirus. Varios critican las medidas autoritarias en diferentes grados, salvo quien justifica la falta de libertad en aras de la salud, considerando que la contingencia pasará (Lipovetsky, 2020a, 2020b, 2020c); sin embargo, otros sostienen que llegó para quedarse (Han, 2020b; García Canclini, 2020; Agamben, 2020b).

La confianza -o la falta de ésta- es otra cuestión que incide en la política actual (Harari, 2020a; Lipovetsky, 2020a, 2020b, 2020c; Wieviorka, 2020). La tecnología es otro punto que destacar entre quienes creen que se va hacia un modelo de vigilancia digital y control totalitario, como Agamben (2020a) y Han (2020a). Este último se distanciaba anteriormente de Lipovetsky (2020a, 2020b, 2020c), pero ahora comparte con él la pujanza del sistema capitalista tras la pandemia. Es un baile de posiciones, ideas, encuentros y desencuentros.

Lo anterior es un breve resumen de algunos puntos que muestran las prospectivas narradas por los autores; recordemos que el objetivo inicial de este texto es describir y reflexionar.

\section{Juntar y sumar}

Finalmente, hay un mayor porcentaje de miradas optimistas y positivas que pregonan la oportunidad de la crisis, si bien se distinguen por las propuestas futuras sobre la sociedad que esbozan. Los menos son quienes mantienen una postura pesimista, en la cual el riesgo impera y lo negativo será lo que domine en la nueva o en la actual sociedad, acentuando el consumismo, el miedo, la injusticia y la opresión. ${ }^{17}$ En general, se habla de transformaciones sociales, económicas, políticas, culturales, tecnológicas e incluso

17 Reiteramos, como se dijo, que hay relatos difíciles de clasificar, pues plantean cosas positivas y negativas. Confieso que, tal vez, la búsqueda estuvo influenciada por la esperanza de que la sociedad mejore, por lo que, consciente o inconscientemente, se valoró y observó más dicha postura. 
de ideas (Wieviorka, 2020b); a las que habría que añadir las epistemológicas (de Sousa Santos, 2020) y las paradigmáticas (Kuhn, 1986).

Las peores distopías ayudan tanto como las mejores utopías, o quizá incluso más, en el sentido de darnos cuenta de las posibilidades y evitarlas conscientemente. Así que las miradas de riesgo o pesimismo, como queramos enunciarlas, sirven tanto como las proyecciones esperanzadoras, como se dijo en un inicio al respecto de las vanas esperanzas o la movilización del riesgo. Se trata, como se ha reiterado ya en varias ocasiones, de pensar juntos y juntas. De hacer una reflexión al interior, como introspección de la propia vida, para llegar a ser lo que realmente ya somos: seres humanos (Rogers, 1992). Asimismo, hacer una reflexión hacia afuera del colectivo humano para llegar a ser lo que también ya somos: seres biológicos que forman parte del planeta Tierra y de la vida, que tienden a desarrollar todo su potencial (Esteva, 2020).

\section{La comprensión presente y los retos del futuro}

Más allá de las perspectivas e interpretaciones que aquí se revisan, objetivo del artículo, tal vez estemos ya en una sociedad difícil de analizar con las teorías conocidas; de ahí las contradicciones entre los pensadores y en cada uno de sus relatos. Quizá ya estemos, sin saberlo, en la era del capitalismo de la vigilancia que "reclama unilateralmente para sí la experiencia humana, entendiéndola como una materia prima gratuita que puede traducir en comportamiento" (Zuboff, 2020, p. 21). ${ }^{18}$ Se empujan, estimulan y persuaden ciertas conductas para dirigirlas a resultados rentables; no sólo se conocen los comportamientos: ahora hasta se moldean. No se trata de automatizar información para la gente; se trata de automatizar a la gente. No somos los clientes del capitalismo, tampoco representamos el dicho de que "cuando el producto es gratis, el producto eres tú" (Zuboff, 2020, p. 24); más bien, somos "los objetos de una operación tecnológicamente avanzada de extracción de materia prima a la que resulta cada vez más difícil escapar" (Zuboff, 2020, p. 21); los clientes son las empresas que comercian con los comportamientos en los mercados organizados. Así, estamos en-

18 Este libro se publicó en inglés en 2018; evidentemente, fue escrito antes de la pandemia; no obstante, su contenido coincide con algunas de las prospectivas sociológicas esbozadas en estas páginas. 
cadenados y contentos de estarlo. ${ }^{19} \mathrm{El}$ poder se acumula gracias al conocimiento: conocen todo de nosotros; nosotros nada de ellos. Predicen nuestro futuro en beneficio de otros, no de nosotros. Lo cual implica usar la fuerza, saltarse la autonomía individual y la democracia.

¿Por qué no se habla mucho de esto? Porque no tiene precedentes y lo que no tiene precedentes resulta difícilmente reconocible: "necesitamos observar y analizar con nuevos ojos los fenómenos, y también hallar nuevos nombres con los que designarlos, si queremos llegar a captar y comprender lo que no tiene precedentes como preludio imprescindible de cualquier forma eficaz de rebatirlo" (Zuboff, 2020, p. 29).

A la luz de esta reflexión, se podría pensar en lo que ocurrió en el 2020. El problema no es la tecnología, sino su intencionalidad y empleo. El avance hacia un mayor control social y político está claro -como pasó después del 11 de septiembre de 2001-; a lo que hay que añadir lo que algunos identifican como control mental (Baños, 2020). O tal vez sólo hay que sincronizar la vida personal con las ilusiones colectivas dominantes, como sugiere Harari (2013).

Aquí se invita a pensar y repensar desde la duda -como la madre de la ciencia- el virus, la pandemia, el confinamiento, las medidas sanitarias, la crisis económica y el autoritarismo político. ¿A quién ha beneficiado?, ¿para qué ha servido en el momento en el que lee estas palabras? Lo cual no significa que, dentro del caos generado, no se pueda obtener aprendizaje o que sea imposible imaginar otras sociedades más justas y humanas.

Ante lo que se ha nombrado capitalismo del desastre, del caos, de la vigilancia, ante la supremacía financiera, el tecnoglobalismo de los megacapitalistas, ante lo que se dice de la era tecnodigital, el big data, el algoritmo, la inteligencia artificial y el transhumanismo, hay que reflexionar desde la serenidad, aprender, proyectar. Frente a las narrativas utópicas esperanzadoras, optimistas, que dibujan futuros más justos, cercanos, humanos, hay que pensar con calma y reprogramarse. Hay que pensar también si es posible unir proyectos, buscar equilibrios, encontrar el camino medio, anhelado y deseable. No creer que tenemos la razón. Escuchar a la vida (Frankl, 1983) y cómo ésta conspira para crear más vida (Champetier de Ribes, 2020). Estar pendiente del otro y de la otra, quienes no son enemigos por tener una opinión contraria a la nuestra o por ser fuentes de contagio

19 Es lo que contempla la Agenda 2030 (Vidal, 2020). 
viral; son seres humanos, como tú y como yo; confundidos, desolados, ilusionados, vivos.

Lo que aquí nos interesa, como se mencionó, es la posibilidad de escucharnos para reflexionar internamente y proyectar un futuro de la humanidad según teorías, enfoques, opiniones, en un momento convulso y crítico de la historia de la humanidad - no catastrofista, como hay quien augura, ni de despertar iluminado, como otros creen-, en un cambio de sistema y de las formas de vida como las hemos entendido hasta el día de hoy; incluyendo recuperar y conservar valores que se consideren dignos. Ante las crisis, hay conflictos y aires de cambio; sería bueno romper esquemas dualistas y abrirse a la complejidad y diversidad humanas.

Se dice que el cambio de paradigma pasa por oír todas las voces, miradas y lecturas sobre la pandemia, sobre cómo estábamos viviendo. Es necesario escucharnos y dialogar -no excluir perspectivas porque todo el mundo aporta algo, quizá en pos del mencionado equilibrio-, con respeto y comprensión - cada quien tiene sus bagajes culturales, políticos- y sin gurús -intelectuales, científicos, políticos, filántropos-, sino más bien hacer una introspección -hay información, nuevo conocimiento biológico, médico, social, que hay que reconvertir en sabiduría-, lo cual cada lector y lectora de este trabajo ha de realizar por su cuenta y riesgo - confío que con respeto, afecto y ecuanimidad-.

\section{Referencias bibliográficas}

Agamben, G. (2020a). La invención de la epidemia. En G. Agamben et al. (coords.), Sopa de Wuhan (pp. 17-20). ASPO. http://iips.usac.edu.gt/ wp-content/uploads/2020/03/Sopa-de-Wuhan-ASPO.pdf

Agamben, G. (2020b). Aclaraciones. En M. Svampa et al., La fiebre. Pensamiento contemporáneo en tiempos de pandemias (pp. 17-38). ASPO. http://www.antropologiadelcuerpo.com/index.php/publicaciones/ reflexiones-en-tiempo-de-aislamiento-social/992-la-fiebre

Agamben, G. (2020c). ¿En qué punto estamos? La epidemia como política. Quodlibet.

Andréu, J. (2002). Las técnicas de análisis de contenido: Una revisión actualizada. Fundación Centro de Estudios Andaluces.

Attali, J. (2012). Breve historia del futuro. Paidós.

Augé, M. (2007). Futuro. Adriana Hidalgo. 
Badiou, A. (2020). Sobre la situación epidémica. En G. Agamben et al. (coords.), Sopa de Wuhan (pp. 67-78). ASPO. http://iips.usac.edu.gt/ wp-content/uploads/2020/03/Sopa-de-Wuhan-ASPO.pdf

Baños, P. (2020). El dominio mental. Ariel.

Bauman, Z. (2007). Miedo líquido. La sociedad contemporánea y sus temores. Paidós.

Bauman, Z. (2017). Retrotopía. Paidós.

Beck, U. (2002). La sociedad del riesgo: Hacia una nueva modernidad. Paidós.

Beck, U., Giddens, A. y Lash, C. (1997). Modernización reflexiva. Alianza Universidad.

Borón, A. (2020). La pandemia y el fin de la era neoliberal. En Pensar la pandemia. Observatorio social del coronavirus (pp. 1-6). CLACSO. https://www.clacso.org/la-pandemia-y-el-fin-de-la-era-neoliberal/

Bringel, B. y Pleyers, G. (2020). Introducción. La pandemia y sus ecos globales. En B. Bringel y G. Pleyers (eds.), Alerta global (pp. 9-25). CLACSO. https://www.clacso.org/wp-content/uploads/2020/08/ Alerta-global.pdf

Butler, J. (2020a). Capitalism has its limits. En B. Bringel y G. Pleyers (eds.), Alerta global (pp. 313-325). FLACSO. http://iips.usac.edu.gt/wp-content/uploads/2020/03/Sopa-de-Wuhan-ASPO.pdf

Butler, J. ( 2020b, 30 de mayo). El capitalismo pandémico hace desechable la vida de los trabajadores. Milenio. https://www.milenio.com/cultura/ judith-butler-el-coronavirus-y-el-capitalismo-pandemico

Butler, J. (2020c, 30 de julio). En marzo se venía un mundo mejor, pero se cuidó la salud... de la economía. El Clarín. https://www.clarin.com/ cultura/judith-butler-coronavirus-habla-vidas-consideran-dispensables-favor-salud-economia-_0_tG_MAHmkS.html

Castel, R. (2004). La inseguridad social: ¿Qué es estar protegido? Manantial. Champetier de Ribes, B. (2020). Los desafíos de la vida actual. Gaia.

Chomsky, N. (2020a, 21 de abril). Pandemia, un fallo colosal del neoliberalismo. El Universal. https://www.eluniversal.com.mx/cultura/ letras/pandemia-de-coronavirus-fallo-colosal-del-neoliberalismo-chomsky

Chomsky, N. (2020b, 11 de septiembre). La supervivencia de la democracia está en juego. Infobae. https://www.infobae.com/cultura/2020/09/11/ noam-chomsky-la-supervivencia-de-la-democracia-esta-en-juego/

Douglas, M. y Wildavsky, A. (1983). Risk and culture: An Essay on the Selec- 
tion of Technological and Environmental Dangers. University of California Press.

Escobar, A. (2020a). El pensamiento en tiempos de pospandemia. En O. Quijano y C. Corredor (comps.), Pandemia al sur (pp. 31-54). Prometeo. https://www.researchgate.net/publication/345694098_ Pandemia_al_Sur

Escobar, A. (2020b). Transiciones post-pandemia en clave civilizatoria. En B. Bringel y G. Pleyers (eds.), Alerta global (pp. 313-325). CLACSO. http://biblioteca.clacso.edu.ar/clacso/se/20200826014541/Alerta-global.pdf

Esteva, G. (2020). El día después. En O. Quijano y C. Corredor (comps.), Pandemia al sur (pp. 55-67). Prometeo. https://prometeo.publica.la/library/ publication/v2-quijano-y-corredor-pandemia-al-sur-1605036086

Fairclough, N. (1994). Discourse and Social Change. Polity Press.

Frankl, V. (1983). El hombre en busca de sentido. Herder.

Fukuyama, F. (1992). El fin de la historia y el último hombre. Planeta.

García Canclini, N. (2020, 6 de abril). Dictadura sanitaria por coronavirus y vigilancia corporativa generalizada. Antropología del cuerpo y la performance. http://www.antropologiadelcuerpo.com/index. php/publicaciones/reflexiones-en-tiempo-de-aislamiento-social/984-garcia-canclini-la-dictadura-sanitaria-por-el-coronavirus-y-la-vigilancia-corporativa-g

González, G., Caballero, J. y Chávez, G. (2011). Las metáforas de la influenza humana A (H1N1) en México: el escenario nacional al descubierto. Una aproximación a través de la prensa mexicana. Comunicación y sociedad, (16), 105-132.

Giddens, A. (1994). Consecuencias de la modernidad. Alianza Universidad.

Han, B.-Ch. (2020a). La emergencia viral y el mundo de mañana. En G. Agamben et al. (coords.), Sopa de Wuhan (pp. 97-112). ASPO. http:// iips.usac.edu.gt/wp-content/uploads/2020/03/Sopa-de-WuhanASPO.pdf

Han, B.-Ch. (2020b, 22 de marzo). La emergencia viral y el mundo de mañana. El Pais. https://elpais.com/ideas/2020-03-21/la-emergencia-viraly-el-mundo-de-manana-byung-chul-han-el-filosofo-surcoreanoque-piensa-desde-berlin.html

Harari, Y. N. (2013). De animales a dioses. Debate.

Harari, Y. N. (2015). Homo Deus. Debate. 
Harari, Y. N. (2020a, 10 de abril). Esto no es la peste negra. No es como si la gente muriera y no tuviéramos ni idea de qué les mata. BBC. https:// www.bbc.com/mundo/noticias-52247987

Harari, Y. N. (2020b, 6 de noviembre). Toda crisis ofrece también una oportunidad. Unesco. https://es.unesco.org/courier/2020-3/ yuval-noah-harari-toda-crisis-ofrece-tambien-oportunidad

Harari, Y. N. (2020c, 14 de septiembre). Nos esperan cosas muchísimo peores que la covid-19 si no tratamos el problema medioambiental. The Conversation. https://theconversation.com/harari-nos-esperan-cosas-muchisimo-peores-que-la-covid-19-si-no-tratamos-el-problema-medioambiental-152059

Harvey, D. (2020). Política anticapitalista en tiempos de COVID-19. En G. Agamben et al. (coords.), Sopa de Wuhan (pp. 79-96). ASPO. http://iips. usac.edu.gt/wp-content/uploads/2020/03/Sopa-de-Wuhan-ASPO.pdf

Kuhn, T. (1986). La estructura de las revoluciones científicas. Fondo de Cultura Económica.

Laje, A. (2020a). El poder en tiempos de pandemia. En C. Beltramo y C. Polo (eds.), Pandemonium. ¿De la pandemia al control total? (pp. 66-74). Populations Research Institute.

Laje, A. (2020b). La cura: ¿reseteo o restauración? En C. Beltramo y C. Polo (eds.), Pandemonium II. La Cura (pp. 17-23). Populations Research Institute.

Latour, B. (2020, 29 de mayo). ¿Qué medidas se pueden pensar para evitar el regreso del modelo precrisis? Climaterra. https://www.climaterra. org/post/latour-qué-medidas-se-pueden-pensar-para-evitar-elregreso-del-modelo-precrisis

Lipovetsky, G. (2020a, 3 de abril). Tras el coronavirus sólo crecerá la desconfianza hacia el poder. La Vanguardia. https://www.lavanguardia.com/ politica/20200403/48282784962/lipovetsky-tras-el-coronavirus-solo-crecera-la-desconfianza-hacia-el-poder.html

Lipovetsky, G. (2020b, 19 de noviembre). Tratar la salud como un negocio nos estaba llevando al desastre. El País. https://elpais.com/ retina/2020/11/19/tendencias/1605768595_881573.html

Lipovetsky, G. (2020c, 9 de diciembre). La semiótica de una pandemia. El Tiempo. https://www.eltiempo.com/mundo/mas-regiones/ gilles-lipovetsky-habla-de-los-efectos-de-la-pandemia-en-la-sociedad-553779 
Lipovetsky, G. y Charles, S. (2008). Los tiempos hipermodernos. Anagrama. Luckas, M. (2020). La tiranía de los algoritmos. En C. Beltramo y C. Polo (eds.), Pandemonium. ¿De la pandemia el control total? (pp. 45-56). Populations Research Institute.

Lyotard, J.-F. (2000). La condición posmoderna. Cátedra.

Maffesoli, M. (2020, marzo). La crisis del Coronavirus o el gran retorno de lo trágico. Climaterra. https://www.climaterra.org/post/michel-maffesoli-la-crisis-del-coronavirus-o-el-gran-retorno-de-lo-trágico

Mercola, J. (2020, 31 de octubre). Todo lo que necesita saber sobre "El Gran Reinicio". Mercola. https://articulos.mercola.com/sitios/articulos/ archivo/2020/10/31/el-gran-reinicio.aspx?cid_source=espan1\&cid_medium=email\&cid_content=art1ReadMore\&cid=20201031\&mid=DM693042\&rid=999956015

Morin, E. (1999). El método. El conocimiento del conocimiento. Cátedra.

Morin, E. (2011). La vía para el futuro de la humanidad. Paidós.

Morin, E. (2020, 13 de marzo). Lo que el coronavirus nos está diciendo. Climaterra. https://www.climaterra.org/post/lo-que-el-coronavirus-nos-está-diciendo-por-edgar-morin

Niño-Becerra, S. (2020). Capitalismo 1679-2065. Ariel.

Ramonet, I. (2020, 25 de abril). La pandemia y el sistema-mundo. La Jornada. https://www.jornada.com.mx/ultimas/mundo/2020/04/25/ ante-lo-desconocido-la-pandemia-y-el-sistema-mundo-7878.html

Rifkin, J. (2020, 21 de abril). Todas mis esperanzas están depositadas en la generación milenial. Telos, (113), 26-34. https://telos.fundaciontelefonica.com/portada-telos-113-jeremy-rifkin-todas-mis-esperanzas-estan-depositadas-en-la-generacion-milenial/

Rodríguez, G., Gil, J. y García, E. (1996). Metodología de la investigación cualitativa. Aljibe.

Rogers, C. (1992). El proceso de convertirse en persona. Paidós.

Schwab, K. y Malleret, T. (2020). COVID-19: The Great Reset. World Economic Forum.

Sousa Santos, B. de (2020). La cruel pedagogía del virus. CLACSO.

Strauss, A. L. y Corbin, J. (1990). Basics of qualitative research: Grounded Theory, procedures and techniques. Sage Publications.

Svampa, M. (2020). Reflexiones para un mundo post-coronavirus. En M. Svampa et al., La fiebre. Pensamiento contemporáneo en tiempos de pandemia (pp. 17-38). ASPO. 
Vidal, C. (2020). El mundo que cambia. Patriotismo frente a agenda globalista. Austin Agency.

Villamor, J. (2020). La (des)información es poder. En C. Beltramo y C. Polo (eds.), Pandemonium. ¿De la pandemia al control total? (pp. 26-37). Populations Research Institute.

Wallerstein, I. (1998). El capitalismo histórico. Siglo XXI Editores.

Wieviorka, M. (2020a, 3 de mayo). Habla el reconocido sociólogo de la Escuela de Altos Estudios de Ciencias Sociales de París. Página 12. https:// www.pagina12.com.ar/263433-michel-wieviorka-en-este-momento-el-poder-esta-desbordado

Wieviorka, M. (2020b, 24 de mayo). Coronavirus: Entramos en una fase de la modernidad donde el riesgo y el sentido de ausencia de seguridad serán centrales. La Nación. https://www.lanacion.com.ar/ el-mundo/michel-wieviorka-entramos-en-una-fase-de-la-modernidad-donde-el-riesgo-y-el-sentido-de-ausencia-de-seguridad-seran-centrales-nid2368931/

World Economic Forum (2020, 4 de junio). "Una oportunidad de oro". Su Alteza Real el Príncipe de Gales y otros líderes sobre el Gran Reinicio. https://es.weforum.org/agenda/2020/06/una-oportunidad-de-oro-el-principe-de-gales-y-otros-lideres-sobre-el-granreinicio/

Zibechi, R. (2020). A las puertas de un nuevo orden mundial. En G. Agamben et al. (coords.), Sopa de Wuhan (pp. 113-118). ASPO. http://iips.usac. edu.gt/wp-content/uploads/2020/03/Sopa-de-Wuhan-ASPO.pdf

Zizek, S. (2020a). El coronavirus es un golpe al capitalismo a lo Kill Bill. En G. Agamben et al. (coords.), Sopa de Wuhan (pp. 21-28). ASPO. http:// iips.usac.edu.gt/wp-content/uploads/2020/03/Sopa-de-WuhanASPO.pdf

Zizek, S. (2020b). Pandemia. Anagrama.

Zuboff, S. (2020). La era del capitalismo de la vigilancia. Paidós. 